\title{
PENGARUH KINERJA KEUANGAN TERHADAP RETURN SAHAM DENGAN MENJADIKAN KEBIJAKAN DIVIDEN SEBAGAI VARIABEL MODERATE PADA PERUSAHAAN YANG TERDAFTAR DI JAKARTA ISLAMIC INDEKS ( JII 2007 - 2011)
}

\author{
Angga kurniawan \\ Universitas muhammadiyah metro \\ angga22.umm@gmail.com
}

\begin{abstract}
The company's financial performance is one of the factors seen by investors as a consideration to invest funds in a company by making the financial statements as a source of information. Good and bad corporate performance can show how much profit can be earned each year and will have an impact on management in setting dividend policy for investors. This study was conducted to determine the effect of financial performance on stock returns by making dividend policy as a moderate variable.

Objects taken in this study amounted to 7 companies listed on the Jakarta Islamic Index (JII) for 5 consecutive years from 2007-2011. Dependent variable of this research is stock return, independent variable include Current Ratio, Return on Asset, Return on Equity, Debt to Equity Ratio, and Total Turnover Asset, while dividend policy (Dividend Payout Ratio) as moderate variable. The method used in this study is Multiple Linear Regression Method and Moderate Regression Analysis Method (Moderate Regrestion Analysis).

Based on the results of multiple linear regression analysis seen from the value of significance shows that $C R, R O A, R O E$, and DER does not significantly influence the stock return, whereas TATO shows the result that there is a significant influence on stock return. The result of moderate regression analysis shows that the dividend policy is not able to moderate the effect of financial performance on stock return.
\end{abstract}

Keywords: Financial performance (CR, ROA, ROE, DER, TATO), stock return, dividend policy (DPR).

\section{LATAR BELAKANG}

Kinerja keuangan perusahaan merupakan salah satu faktor yang dilihat investor untuk menentukan dalam membeli saham. Bagi perusahaan, menjaga dan meningkatkan kinerja keuangan adalah suatu keharusan agar saham yang terdaftar di Jakarta Islamic Index (JII) tersebut tetap eksis dan tetap diminati oleh investor. Laporan keuangan yang diterbitkan perusahaan merupakan cerminan dari kinerja keuangan dari sebuah perusahaan. Laporan keuangan merupakan hasil akhir dari proses akuntansi yang telah disusun dengan tujuan untuk memberikan informasi keuangan suatu entitas ekonomi. Informasi keuangan tersebut dapat digunakan oleh para pemakai yang berkepentingan dalam pengambilan keputusan.

Informasi keuangan yang digunakan untuk pengambilan keputusan tersebut nantinya akan dapat digunakan oleh pihak eksternal dan internal perusahaan untuk melihat informasi yang dibutuhkan. Dalam hal ini pihak-pihak eksternal terutama investor yang akan melihat informasi keuangan yang dibutuhkan apabila investor ingin menanamkan modalnya serta melihat seberapa besar kemajuan perusahaan tersebut di masa depan dan memberikan keuntungan baginya. Investor juga dapat menanamkan sahamnya di perusahaan-perusahaan yang memiliki nilai yang baik di masa datang serta memiliki risiko yang cenderung stabil.

Pasar modal merupakan salah satu sarana yang dapat dijadikan untuk memobilisasi dana, baik dari dalam negeri maupun luar negeri. Hal ini terbukti banyaknya kegiatan-kegiatan di pasar modal (bursa). Transaksi jual-beli saham yang terjadi pada bursa efek dapat digambarkan dengan tingkat harga saham yang tercatat pada bursa efek. Naik turunnya harga saham dipengaruhi oleh laba dan dividen. Laba digambarkan dengan harga saham sedangkan dividen digunakan untuk mengukur harga saham yang didalamnya terdapat nilai intrinsik yang akan menggambarkan harga saham. 
Laba perusahaan dapat menjadi acuan investor untuk melakukan investasi. Dari informasi laba bersih perusahaan, investor dapat menilai pertumbuhan perusahaan. Dividen yang dibayarkan perusahaan pada dasarnya berasal dari laba bersih perusahaan. Dividen yang diberikan oleh perusahaan dapat berpengaruh positif pada sikap investor dan dapat menarik investor untuk berinvestasi. Akan tetapi, banyak juga perusahaan yang tidak memberikan dividen melainkan investor hanya berinvestasi saham pada perusahaan tersebut. Harga saham di bursa efek akan ditentukan oleh kekuatan permintaan dan penawaran. Pada saat permintaan saham meningkat, maka harga saham tersebut akan cenderung meningkat. Sebaliknya, pada saat banyak orang yang menjual saham, maka harga saham tersebut cenderung akan mengalami penurunan. Dengan diberikannya dividen kepada investor yang berasal dari laba bersih perusahaan dapat menarik investor untuk membeli saham perusahaan yang nantinya akan sangat berpengaruh terhadap harga saham perusahaan tersebut. Dengan kata lain, investor kembali berinvestasi pada saham perusahaan tersebut sehingga membuat likuiditas saham perusahaan meningkat semakin tinggi. Sehingga tidak menutup kemungkinan bagi investor lain untuk berinvestasi pada saham perusahaan yang sama. Hal tersebut tentunya berpengaruh terhadap naik turunnya harga saham.

Terdapat dua pendekatan dasar untuk menganalisis dan memilih saham, yaitu analisis teknikal dan analisis fundamental. Analisis Teknikal (technical analysis), yaitu menentukan nilai saham dengan menggunakan data pasar dari saham atau data dari luar perusahaan (misalnya harga dan volume). Analisis Fundamental, yaitu menentukan nilai saham dengan menggunakan data yang berasal dari keuangan perusahaan yang berbentuk informasi laporan keuangan (misalnya laba dividen yang dibayar, penjualan, dan lain sebagainya) (Jogiyanto, 2007). Kedua pendekatan ini dapat digunakan sebagai dasar bagi investor untuk memprediksi return, risiko atau ketidakpastian, jumlah, waktu, dan faktor lain yang berhubungan dengan aktivitas investasi di pasar modal. Apabila investor menginginkan return yang lebih tinggi, maka dia harus menanggung risiko yang lebih tinggi pula. Semakin tinggi efisien kinerja keuangan perusahaan, maka akan semakin besar pula tingkat return yang akan dihasilkan.

Untuk menilai kinerja keuangan perusahaan diperlukan rasio-rasio keuangan, karena rasio keuangan ini dapat digunakan untuk menginterpretasikan tingkat keuangan dalam bisnis, mengukur efektifitas manajemen, untuk mengukur kinerja perusahaan dan sebagai suatu alternatif untuk menguji apakah informasi keuangan yang dihasilkan oleh akuntansi keuangan bermanfaat untuk melakukan pengklasifikasian atau prediksi terhadap return saham di pasar modal. Rasio keuangan tersebut adalah rasio profitabilitas, rasio likuiditas, rasio solvabilitas dan rasio aktivitas. Alat ukur rasio keuangan meliputi Current Ratio, Quick Ratio, Debt Equity Ratio, Debt Ratio, Net Profit Margin, Total Asset Turnover, Return on Equity, Return on Asset, Earnings Per Share.

Terdapat cukup banyak penelitian yang mengkaji pengaruh berbagai indikator kinerja keuangan terhadap return saham. Rosyadi (2002) melakukan penelitian tentang keterkaitan kinerja keuangan terhadap harga saham pada perusahaan- perusahaan go public di BEJ yang pernah termasuk dalam 20 mist active saham berdasarkan frekuensi perdagangan periode tahun 1993-1994. Penelitian ini menggunakan Earnings per Share (EPS), Return on Assets (ROA), Net Profit Margin (NPM), dan Debt to Equity Ratio (DER) sebagai indikator pengukur kinerja keuangan perusahaan. Hasil penelitiannya menunjukkan bahwa perubahan EPS, ROA, dan NPM berpengaruh secara parsial dan simultan terhadap perubahan harga saham, sedangkan perubahan DER tidak berpengaruh secara parsial terhadap perubahan harga saham.

Raharjo (2005), di dalam penelitiannya yang berjudul Analisis Kinerja Keuangan Terhadap Return Saham Pada Perusahaan LQ-45 di Bursa Efek Jakarta. Penelitian tersebut menyimpulkan bahwa rasio PER, PBV, OPM, NPM, ROA, ROE, dan EPS berpengaruh positif terhadap return saham. Sedang rasio DER berpengaruh negatif terhadap return saham.

Wulandari dan Sasongko (2006) melakukan penelitian mengenai pengaruh EVA dan rasio- rasio profitabilitas terhadap harga saham. Hasil penelitian tersebut menyimpulkan bahwa EPS berpengaruh signifikan terhadap harga saham sedangkan ROA, ROE, ROS, Basic Earning Power, dan EVA tidak berpengaruh signifikan terhadap harga saham. 
Pradhono dan Christiawan (2005) yang melakukan penelitian dengan judul Pengaruh EVA, Residual Income, Earnings, dan Arus Kas Operasi Terhadap Return Saham yang Diterima oleh Pemegang Saham. Di dalam penelitiannya menghasilkan bahwa variabel EVA tidak mempunyai pengaruh yang signifikan terhadap return yang diterima oleh pemegang saham, variabel residual income tidak mempunyai pengaruh yang signifikan terhadap return saham, lalu variabel earnings mempunyai pengaruh yang signifikan terhadap rerurn saham, dan variabel arus kas operasi mempunyai pengaruh signifikan terhadap return yang diterima oleh pemegang saham.

Penelitian ini hampir sama dengan penelitian-penelitian yang telah dilakukan sebelumnya. Namun yang membedakan penelitian ini dengan penelitian sebelumnya adalah rasio yang digunakan hanya CR, DER, ROA, ROE, dan TATO serta menambahkan kebijakan dividen sebagai variabel moderate untuk memperkuat atau memperlemah pengaruh kinerja keuangan terhadap return saham dan objek yang diteliti merupakan perusahaan yang terdaftar di Jakarta Islamic Index ( JII)

Berdasarkan latar belakang yang telah diungkapkan maka tujuan dari penelitian ini adalah ingin mengetahui apakah faktor- faktor Current Ratio, Return on Asset, Return on Equity, Debt to Equity Ratio, dan Total Asset Turnover mempengaruhi return saham dengan kebijakan dividen sebagai variabel moderate. Penelitian ini dilakukan untuk memperoleh bukti statistik secara empiris mengenai apakah terdapat pengaruh antara kinerja keuangan perusahaan terhadap return saham dengan menjadikan kebijakan dividen sebagai variabel moderate.

\section{TINJAUAN PUSTAKA} Laporan Keuangan

Terdapat beberapa pengertian laporan keuangan menurut para ahli. Menurut Munawir (2000:31), "Laporan Keuangan merupakan alat yang sangat penting untuk memperoleh informasi sehubungan dengan posisi keuangan dan hasil- hasil yang telah dicapai oleh perusahaan. Menurut Kieso, Weygandt dan Warfiled (2002, p.3), Laporan keuangan adalah suatu proses pencatatan yang merupakan suatu ringkasan dari transaksi keuangan yang terjadi selama tahun buku bersangkutan yang berguna bagi pemakai laporan keuangan dalam pengambilan keputusan.

Menurut Harahap (2004 : 205), Laporan keuangan menggambarkan kondisi keuangan dan hasil usaha suatu perusahaan pada saat tertentu atau jangka waktu tertentu. Sedangkan menurut Riyanto (2001 : 15) menyatakan laporan keuangan memberikan ikhtisar mengenai adanya keuangan suatu perusahaan, di mana neraca mencerminkan nilai aktiva, nilai hutang, dan modal sendiri pada suatu saat tertentu dan laporan keuangan laba/ rugi mencerminkan hasilhasil yang dicapai selama periode tertentu biasanya dalam satu tahun.

Dari beberapa pengertian yang telah dijelaskan sebelumnya dapat disimpulkan bahwa laporan keuangan merupakan hasil dari proses akuntansi yang berisikan mengenai data-data keuangan perusahaan yang dapat dijadikan sebagai dasar pengambilan keputusan bagi pihak yang berkepentingan.

\section{Kinerja Perusahaan}

1. Kinerja Saham

\section{a. Pasar Modal}

Secara umum pasar modal merupakan suatu sistem keuangan yang terorganisasi, termasuk didalamnya adalah bank-bank komersial dan semua lembaga perantara dibidang keuangan serta keseluruhan surat- surat berharga yang beredar. Dalam arti sempit, pasar modal adalah suatu pasar (tempat, berupa gedung) yang disiapkan guna memperdagangkan saham-saham, obligasi- obligasi, dan jenis surat berharga lainnya dengan memakai jasa para perantara pedagang efek. Menurut Husnan (2003), pasar modal merupakan pasar untuk berbagai instrumen keuangan jangka panjang yang bisa diperjualbelikan, baik dalam bentuk hutang maupun modal sendiri, baik yang diterbitkan oleh pemerintah publik authorities maupun 
perusahaan swasta. Dari beberapa pengertian di atas dapat dikatakan bahwa pasar modal adalah salah satu cara yang dapat digunakan oleh perusahaan dalam mengumpulkan dana dengan menjual hak kepemilikan perusahaan kepada masyarakat.

\section{b. Saham}

Saham adalah tanda penyertaan atau kepemilikan seseorang atau badan dalam suatu perusahaan atau perusahaan terbatas yang bertujuan untuk memperoleh hasil berupa keuntungan dari penjualan saham tersebut. Menurut Mishkin (2001, 4), saham adalah suatu sekuritas yang memiliki klaim terhadap pendapatan dan asset sebuah perusahaan. Sekuritas sendiri dapat diartikan sebagai klaim atas pendapatan masa depan seorang peminjam yang dijual oleh peminjam kepada yang meminjamkan, sering juga disebut instrument keuangan (Mishkin: 2001,4). Saham dapat dibedakan menjadi dua yaitu Saham Biasa dan Saham Preferen.

\section{c. Return Saham}

Setiap investor pasti menginginkan return yang tinggi atas investasi yang dilakukannya. Menurut Jogiyanto (2007), return saham adalah hasil yang diperoleh dari investasi. Secara umum return saham adalah pengembalian hasil atau laba yang diperoleh dari kepemilikan saham yang dimilikinya atas investasi yang dilakukan berupa dividen dan capital gain (loss) serta besarnya dinyatakan dalam suatu tingkat persentase tahunan. Adapun return saham dibedakan menjadi dua, yaitu (1) return realisasian merupakan return yang telah terjadi, (2) return ekspektasian merupakan return yang diharapkan akan diperoleh oleh investor di masa yang akan datang.

\section{Kinerja Keuangan}

Penilaian kinerja keuangan perusahaan didefinisikan sebagai Performing Measurement (pengukuran kinerja) yang artinya adalah kualifikasi dan efisisensi perusahaan atau keefektifan dalam pengoperasian bisnis selama periode akuntansi. Sehingga dapat diartikan bahwa kinerja adalah suatu usaha formal yang dilaksanakan perusahaan untuk mengevaluasi efisiensi dan efektivitas dari aktivitas perusahaan yang telah dilaksanakan pada periode waktu. Jadi dapat disimpulkan untuk menilai kinerja keuangan perusahaan dapat menggunakan suatu ukuran atau tolak ukur tertentu. Biasanya ukuran yang digunakan untuk mengukur kinerja keuangan perusahaan adalah rasio atau indeks yang menghubungkan dua atau lebih data keuangan.

\section{a. Rasio Keuangan}

Besarnya peningkatan atau penurunan kinerja perusahaan dapat dilakukan dengan mengukur indikator penting yang terdapat di dalam laporan keuangan sebagai faktor yang menunjukkan tingkat kinerja perusahaan. Alat ukur tersebut dikenal dengan nama Rasio Keuangan. Rasio keuangan adalah alat yang digunakan untuk menganalisis kondisi keuangan dan kinerja perusahaan. Menurut Hardjito, dkk (2005), secara garis besar terdapat 4 jenis rasio keuangan yang dapat digunakan untuk menilai kinerja keuangan perusahaan, yaitu likuiditas (current ratio dan quick ratio), aktivitas (total asset turnover, receivable turnover, inventory turnover, dan receivable turnover in days, leverage (debt to equity ratio dan debt ratio), dan profitabilitas (return on asset,return on equity, gross profit margin, dan net profit margin). 


\section{Kebijakan Deviden}

Pihak manajemen memiliki pengaruh yang penting dalam pengambilan keputusan terutama dalam hal kebijakan dividen. Kinerja perusahaan yang baik atau tidak pasti akan tetap memiliki laba setiap tahunnya. Keputusan yang diambil oleh manajemen terhadap laba yang dihasilkan juga berpengaruh pada kebijakan mengenai besarnya dividen yang akan dibagikan kepada investor. Kebijakan dividen sering dianggap sebagai signal bagi investor dalam menilai baik buruknya perusahaan, hal ini disebabkan karena kebijakan dividen dapat membawa pengaruh terhadap harga saham perusahaan. Dengan demikian seberapa besar porsi laba yang akan dibagikan dalam bentuk dividen dan seberapa besar porsi laba yang akan ditahan untuk diinvestasikan kembali, merupakan masalah yang cukup serius bagi pihak manajemen. Kebijakan dividen mengenai besarnya dividen yang akan dibagikan berbentuk persentase yang diukur dengan rumus sebagai berikut :

$$
D P R=\frac{\text { Dividen yang dibagi }}{\text { EAT }} \times 100 \%
$$

Keterangan:

DPR $=$ Dividen Payout Ratio

EAT $=$ Earnings After Tax (Laba setelah pajak)

\section{Pengembangan Hipotesis}

1. Pengaruh kinerja keuangan terhadap return saham

Kinerja keuangan perusahaan yang baik akan menunjukan tingkat return yang tinggi sedangkan jika kinerja keuangan perusahaan buruk, maka tingkat return yang diharapkan akan rendah. Perkembangan kinerja keuangan sangatlah penting bagi para investor sebagai dasar dalam pengambilan keputusan untuk melakukan investasi, karena tujuan utama para investor untuk menginvestasikan saham adalah untuk memperoleh tingkat return yang setinggi- tingginya. Begitu banyak rasio keuangan yang digunakan untuk mengukur kinerja keuangan perusahaan. Namun rasio keuangan yang digunakan dalam penelitian ini adalah Current Ratio, Return on Asset, Return on Equity, Debt to Equity Ratio, Total Asset Turnover. Dari pembahasan yang telah dijelaskan sebelumnya dapat diturunkan hipotesis sebagai berikut :

$$
\begin{aligned}
& \text { H1 = Current Ratio berpengaruh terhadap return saham. } \\
& \text { H2 = Rasio Return on Asset berpengaruh terhadap return saham. } \\
& \text { H3 = Rasio Return on Equity berpengaruh terhadap return saham. } \\
& \text { H4 = Debt to Equity Ratio berpengaruh terhadap return saham. } \\
& \text { H5 = Total Asset Turnover berpengaruh terhadap return saham. }
\end{aligned}
$$

2. Kebijakan Dividen Sebagai Variabel Moderate pada Pengaruh Kinerja Keuangan Terhadap Return Saham

Penelitian ini menjadikan kebijakan dividen sebagai variabel moderate untuk mengetahui apakah kebijakan dividen ini akan memperkuat atau memperlemah pengaruh kinerja keuangan terhadap return saham. Kebijakan dividen dijadikan sebagai dasar pertimbangan investor untuk berinvestasi. Melalui besarnya dividen yang akan dibagikan akan berkaitan dengan besarnya return saham yang akan diterima oleh pemegang saham. Manajemen akan 
mengambil kebijakan dividen berdasarkan besar atau rendahnya laba yang diperoleh perusahaan. Berdasarkan penjelasan tersebut, maka hipotesis penelitian ini adalah :

H6 = Kebijakan dividen mampu memoderasi pengaruh kinerja keuangan terhadap return saham

\section{Kerangka Berpikir}

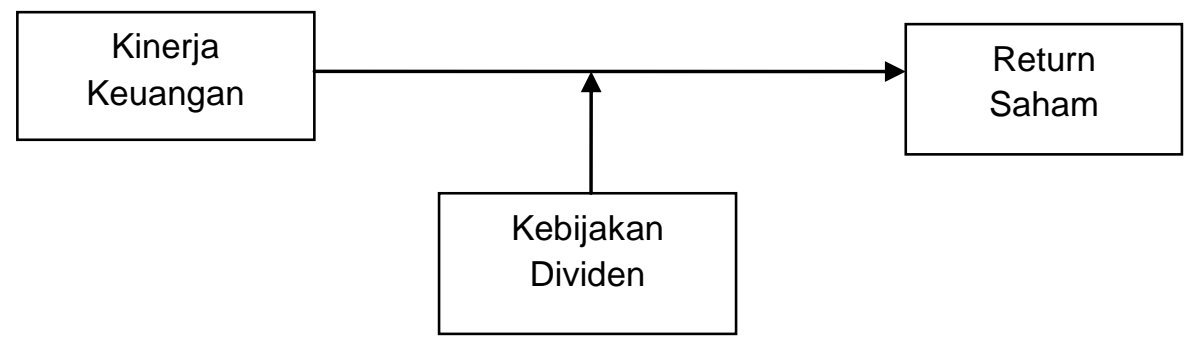

\section{METODA PENELITIAN}

\section{Populasi dan Sampel}

Populasi dalam penelitian adalah seluruh perusahaan manufaktur yang terdaftar di Jakarta Islamic Indeks pada tahun 2007 hingga 2011. Pada periode tersebut perusahaan yang dapat dijadikan sampel dalam penelitian ini adalah 30 perusahaan.

Pengambilan sampel pada penelitian ini menggunakan teknik purposive sampling dan sampel dipilih berdasarkan tujuan atau target tertentu, yaitu pemilihan sampel didasarkan pada pertimbangan yang merupakan tipe pemilihan sampel secara acak di mana informasinya diperoleh dengan pertimbangan- pertimbangan tertentu. Dari populasi yang ada, diambil sampel yang memenuhi kriteria sebagai berikut :

1. Terdaftar di Jakarta Islamic Index (JII) selama periode penelitian, yaitu tahun 2007-2011.

2. Memberikan laporan keuangan tahunan yang lengkap secara periodik kepada JII.

3. Memilki data-data penunjang yang diperlukan untuk menyelesaikan penelitian.

4. Menghasilkan laba sepanjang periode penelitian.

5. Laporan keuangan sudah dipublikasikan

Metode pengumpulan data yang digunakan dalam penelitian ini adalah dengan menggunakan metode dokumentasi. Metode dokumentasi adalah suatu metode dimana data diambil dari sumber-sumber yang relevan (Mudrajad, 2003). Di dalam penelitian ini, metode dokumentasi digunakan untuk merekap data-data laporan keuangan yang dibutuhkan dari tahun 2007-2011. Data yang digunakan dalam penelitian ini adalah laporan keuangan yang telah dipublikasikan.

\section{Variabel}

\section{Variabel Dependen}

Variabel dependen adalah variabel yang dipengaruhi oleh variabel lain. Dalam penelitian ini variabel yang dipengaruhi adalah return saham. Return saham dapat dirumuskan sebagai berikut:

$$
\text { Return Saham }=\frac{P t-P_{t-1}}{P_{t-1}} \times 100 \%
$$

\section{Keterangan:}

$\mathrm{Pt} \quad=$ Harga saham pada tahun $\mathrm{t}$

Pt-1 = Harga saham pada tahun $\mathrm{t}-1$ 


\section{Variabel Independen}

Variabel Independen adalah variabel yang mempengaruhi variabel lain atau dengan kata lain mempengaruhi variabel dependen. Dalam penelitian ini variabel independennya adalah 4 jenis rasio keuangan yang dapat digunakan untuk menilai kinerja keuangan perusahaan, yaitu likuiditas (current ratio), aktivitas (total asset turnover), leverage (debt to equity ratio), dan profitabilitas (return on asset dan return on equity). Dan dalam penelitian ini dapat dirumuskan sebagai berikut untuk dapat melakukan perhitungan untuk memperoleh hasil pengukuran kinerja keuangan pada masing- masing variabel meliputi :

\section{a. Current Ratio (CR)}

Current Ratio (CR) yang semakin tinggi, maka laba bersih yang dihasilkan perusahaan semakin sedikit, karena rasio lancar yang tinggi menunjukkan adanya kelebihan aset lancar yang tidak baik terhadap profitabilitas perusahaan karena aset lancar menghasilkan return yang lebih rendah dibandingkan dengan aset tetap (Hanafi dan Halim, 2003). Current Ratio (CR) dinyatakan dalam bentuk rumus, yaitu :

$$
C R=\frac{\text { Aset Lancar }}{\text { Utang Lancar }} \times 100 \%
$$

b. Return on Asset (ROA)

ROA digunakan untuk melihat tingkat efisiensi operasi perusahaan secara keseluruhan. Semakin tinggi rasio ini, maka semakin baik kinerja perusaan tersebut. (Hanafi, 2004). Hal tersebut dinyatakan dalam rumus berikut :

$$
R O A=\frac{\text { Laba Bersih Setelah Pajak }}{\text { Jumlah Aset }} \times 100 \%
$$

c. Return on Equity (ROE)

Apabila semakin tinggi nilai ROE menunjukkan semakin efisien perusahaan menggunakan modal sendiri untuk menghasilkan laba (Brigham, 2001). ROE dinyatakan dalam rumus sebagai berikut:

$$
\text { ROE }=\frac{\text { Laba Bersih Setelah Pajak }}{\text { Jumlah Modal Sendiri }} \times 100 \%
$$

\section{d. Debt to Equity Ratio ( DER)}

Apabila semakin besar tingkat DER, maka akan semakin tinggi pula hutang yang dimliki sehingga akan menggambarkan tingkat resiko yang relatif tinggi dan menunjukkan bahwa risiko yang akan ditanggung investor juga akan semakin tinggi. DER dinyatakan dalam rumus sebagai berikut :

$$
D E R=\frac{\text { Total Hutang }}{\text { Modal Sendiri }} \times 100 \%
$$

\section{e. Total Asset Turnover (TATO)}

Semakin tinggi rasio Total Asset Turnover, maka semakin efisien penggunaan aset dan semakin cepat pengembalian dana dalam bentuk kas (Halim, 2007). TATO dinyatakan dalam rumus sebagai berikut : 


$$
\text { TATO }=\frac{\text { Penjualan Bersih }}{\text { Total Aset }} \times 100 \%
$$

\section{Variabel Moderate}

Variabel Moderate adalah variabel yang memperkuat ataupun memperlemah hubungan antara satu variabel dengan variabel lainnya. Pada penelitian ini variabl moderate yang dimunculkan adalak kebijakan dividen. Besarnya kebijakan dividen dapat dirumuskan sebagai berikut :

$$
D P R=\frac{\text { Dividen yang dibagi }}{\text { EAT }} \times 100 \%
$$

Keterangan:

DPR $=$ Dividen Payout Ratio

EAT $=$ Earnings After Tax (Laba setelah pajak)

Sebelum dilakukan pengujian regresi berganda, terlebih dahulu dilakukan pengujian asumsi klasik untuk mengetahui apakah data yang digunakan telah memenuhi ketentuan dalam model regresi atau belum.

\section{Uji Asumsi Klasik \\ Uji Normalitas}

Uji Normalitas dalam asumsi klasik bertujuan untuk menguji model dalam regresi yaitu variabel terikat dan variabel bebas, keduanya mempunyai distribusi normal atau tidak. Untuk mengujinya yaitu dengan melihat probabilitas asymp.sig (2-tailed), jika nilai asymp.sig (2-tailed) > 0.05 maka dapat disimpulkan bahwa telah terjadi normalitas dan sebaliknya jika nilai asymp.sig (2-tailed) $<0.05$ maka model regresi tersebut mempunyai distribusi yang tidak normal.

\section{Uji Multikolinearitas}

Uji multikolinearitas digunakan untuk menguji adanya hubungan linear yang sempurna antara variabel independen dalam model. Model regresi yang baik seharusnya tidak terjadi korelasi diantara variabel independen. Terdapat beberapa cara untuk mendeteksi suatu model terdapat multikolinieritas atau tidak, antara lain yaitu diuji dengan menggunakan Variance Inflation Factor (VIF) dan Tolerance Value. Jika nilai VIF di atas 10 atau Tolerance Value di bawah 0,10 maka terjadi multikolinearitas.

\section{Uji Autokorelasi}

Autokorelasi adalah hubungan/korelasi antara data yang satu dengan data yang lainnya dalam suatu variabel (Kurniawati, 2006). Pada umumnya untuk menguji agar sebuah model regresi terdapat autokorelasi dapat menggunakan statistik Durbin-Watson test, yang dikembangkan oleh J. Durbin dan G Watson. Pengujian ini dilakukan dengan membandingkan nilai $\mathrm{d}$ dari hasil perhitungan (atau nilai $d w$ ) dengan nilai du dan dl yang diperoleh dari table Durbin-Watson test.

\section{Uji Heteroskedatisitas}

Uji Heteroskedatisitas digunakan untuk menguji model dalam regresi, yang mengindikasikan adanya kesamaan varian dari residual satu pengamatan ke pengamatan lainnya. Model regresi yang baik adalah model regresi yang homoskedastisitas atau tidak adanya kesamaan varian. Uji heteroskedastisitas dapat dilakukan dengan cara melihat melihat Grafik Plot antara nilai prediksi variabel terikat (dependen) yaitu ZPRED dengan residualnya SRESID. Jika plot tersebar atau tidak mengumpul, tidak membentuk pola $\mathrm{U}$ maupun $\mathrm{U}$ terbalik atau pola 
tertentu yang teratur (bergelombang, melebar kemudian menyempit), maka data bebas dari heteroskedastisitas atau data tersebut homoskedastisitas.

\section{Uji Regresi Linier Berganda}

Teknik regresi linear berganda (multiple regression analysis) dilakukan terhadap model penelitian yang diajukan oleh peneliti dirumuskan sebagai berikut:

$$
\begin{aligned}
& \mathrm{Y}=\alpha+\beta 1 \mathrm{X} 1+\beta 2 \mathrm{X} 2+\beta 3 \mathrm{X} 3+\beta 4 \mathrm{X} 4+\beta 5 \mathrm{X} 5+\varepsilon \\
& \text { Keterangan: } \\
& \mathrm{Y}=\text { Return Saham } \\
& \alpha \quad=\text { Konstanta } \\
& \beta 1, \beta 1,2 \beta 3, . . \text { dst } \quad=\text { Koefisien Regresi } \\
& \mathrm{X} 1 \quad=\text { Current Ratio } \\
& \mathrm{X} 2 \quad=\text { Return on Asset } \\
& \mathrm{X} 3 \quad=\text { Return on Equity } \\
& \text { X4 = Debt to Equity Ratio } \\
& \text { X5 = Total Asset Turnover } \\
& \varepsilon=\text { Error }
\end{aligned}
$$

\begin{tabular}{|c|c|}
\hline Y & $=$ Return Saham \\
\hline$\alpha$ & $=$ Konstanta \\
\hline$\beta 1-\beta 5$ & $=$ Koefisien Regresi \\
\hline $\mathrm{X} 1$ & $=$ Current Ratio \\
\hline $\mathrm{X} 2$ & $=$ Return on Asset \\
\hline $\mathrm{X} 3$ & $=$ Return on Equity \\
\hline $\mathrm{X} 4$ & $=$ Debt to Equity Ratio \\
\hline $\mathrm{X} 5$ & $=$ Total Asset Turnover \\
\hline $\mathrm{Z}$ & = Kebijakan Dividen \\
\hline $\mathrm{X} 1 \mathrm{Z}$ & $=$ Interaksi antara $C R$ dengan kebijakan dividen \\
\hline $\mathrm{X} 2 \mathrm{Z}$ & $=$ Interaksi antara $R O A$ dengan kebijakan dividen \\
\hline $\mathrm{X} 3 \mathrm{Z}$ & $=$ Interaksi antara $R O E$ dengan kebijakan dividen \\
\hline $\mathrm{X} 4 \mathrm{Z}$ & $=$ Interaksi antara $D E R$ dengan kebijakan dividen \\
\hline $\mathrm{X} 5 \mathrm{Z}$ & $=$ Interaksi antara TATO dengan kebijakan dividen \\
\hline & $=$ Eror \\
\hline
\end{tabular}

Dan selanjutnya melakukan pengujian regresi terhadap moderate untuk mengetahui apakah kebijakan dividen akan memperkuat atau memperlemah pengaruh kinerja keuangan terhadap return saham. Pengujian regresi terhadap moderate dapat diukur dengan menggunakan rumus sebagai berikut :

$$
\begin{aligned}
Y=\alpha+\beta 1 X 1+\beta 1 Z+\beta 1 X 1 . Z+\beta 2 X 2+\beta 2 Z+\beta 2 X 2 . Z+\beta 3 X 3+\beta 3 Z+\beta 3 X 3 . Z+ \\
\\
\beta 4 X 4+\beta 4 Z+\beta 4 X 4 . Z+\beta 5 X 5+\beta 5 Z+\beta 5 X 5 . Z+\text { ei }
\end{aligned}
$$

Keterangan :

\section{PEMBAHASAN}

Statistik Deskriptif

Statistik deskriptif adalah suatu alat statistic yang digunakan peneliti untuk menjelaskan dan menganalisis data dengan cara menggambarkan data yang telah terkumpul tanpa maksud membuat kesimpulan secara umum (Kurniawati,2006).

\section{Uji Asumsi Klasik}

\section{Uji Normalitas}

Pengujian normalitas data merupakan salah satu asumsi penting untuk melakukan penelitian yang menggunakan metode regresi. Uji normalitas digunakan untuk mengetahui apakah variabel dependen berdistribusi normal atau tidak normal. Berikut hasil uji normalitas terhadap variabel dependen pada tabel 1 dan memiliki hasil dalam pengujian 
normalitas ini menggunakan uji Shapiro-Wilk dan dari pengujian tersebut menunjukkan hasil asymp. Sig (2-tailed) sebasar 0,270 > 0,05, sehingga dapat dikatakan bahwa data variabel tersebut berdistribusi normal.

Tabel 1

\begin{tabular}{|c|c|c|c|c|c|c|}
\hline & \multicolumn{3}{|c|}{ Kolmogorov-Smirnov $^{\mathrm{a}}$} & \multicolumn{3}{c|}{ Shapiro-Wilk } \\
\cline { 2 - 7 } & Statistic & Df & Sig. & Statistic & df & Sig. \\
\hline Y & 0,180 & 35 & 0,006 & 0,962 & 35 & 0,270 \\
\hline
\end{tabular}

a. Lilliefors Significance

Correction

\section{Uji Autokorelasi}

Uji Autokorelasi digunakan untuk mengetahui apakah terdapat hubungan/korelasi atau tidak antara suatu data dengan data yang lain dalam satu variabel. Penelitian ini menggunakan uji Durbin-Watson untuk mengetahui adanya Autokorelasi atau tidak Berikut merupakan hasil uji Autokorelasi terhadap variabel dependen, independen, dan moderasi. Dari tabel 2 menunjukkan nilai Durbin-Watson sebesar 2,544. Sedangkan nilai dL dan dU dari tabel Durbin-Watson dengan $\alpha=5 \%, \mathrm{n}=35$, dan $\mathrm{k}=5$ menunjukkan nilai $\mathrm{dL}=1,16$ dan $\mathrm{dU}=1,57$. Sehingga nilai $4-\mathrm{dL}=4-1,16=2,84$ dan nilai 4 - $\mathrm{dU}=4-1,80=2,20$. Nilai Durbin-Watson sebesar 2,544 terletak di antara 2,20 dan 2,84 atau dapat dikatakan terletak pada grey area, maka dapat disimpulkan bahwa model regresi tidak terdapat autokorelasi sebagian.

Tabel 2

\begin{tabular}{|c|c|c|c|c|c|c|c|c|c|c|}
\hline \multirow[b]{2}{*}{ Model } & \multirow[b]{2}{*}{$\mathrm{R}$} & \multirow{2}{*}{$\begin{array}{c}\mathrm{R} \\
\text { Squar } \\
\mathrm{e}\end{array}$} & \multirow{2}{*}{$\begin{array}{l}\text { Adjust } \\
\text { ed R } \\
\text { Square }\end{array}$} & \multirow{2}{*}{$\begin{array}{l}\text { Std. Error } \\
\text { of the } \\
\text { Estimate }\end{array}$} & \multicolumn{5}{|c|}{ Change Statistics } & \multirow[b]{2}{*}{$\begin{array}{l}\text { Durbin- } \\
\text { Watson }\end{array}$} \\
\hline & & & & & $\begin{array}{l}\text { R Square } \\
\text { Change }\end{array}$ & $\begin{array}{c}\mathrm{F} \\
\text { Change }\end{array}$ & df1 & df2 & $\begin{array}{l}\text { Sig. F } \\
\text { Change }\end{array}$ & \\
\hline 1 & $\underset{\mathrm{a}}{0,532}$ & 0,283 & 0,130 & 0,02199 & 0,283 & 1,846 & 6 & 28 & 0,126 & 2,544 \\
\hline
\end{tabular}

a. Predictors: (Constant), Z (DPR), X3 (ROE), X4 (DER), X5 (TATO), X1 (CR), X2 (ROA)

b. Dependent Variable: Y (Return Saham )

\section{Uji Multikolienaritas}

Pengujian multikolinearitas digunakan untuk mengetahui_dalam suatu model regresi apakah terdapat hubungan linier di antara variabel-variabel independen. Dengan adanya nilai Eigenvalue untuk CR $\left(X_{1}\right)=0,771, \operatorname{ROA}\left(X_{2}\right)=0,559, \operatorname{ROE}\left(X_{3}\right)=0,258, \operatorname{DER}\left(X_{4}\right)=$ 0,089 , TATO $\left(X_{5}\right)=0,022$, dan DPR $(Z)=0,001$. Nilai tersebut tidak mendekati nol, maka dapat disimpulkan bahwa model regresi yang digunakan tidak terdapat multikolinearitas.

\section{Uji Heterokedastis}

Hasil dari pengujian heterokedastis menunjukkan hasil bahwa titik-titik menyebar secara acak baik di atas maupun di bawah angka 0 dari sumbu $\mathrm{Y}$ sehingga dapat disimpulkan persamaan regresi tidak terjadi heterokedastis.

\section{Uji Regresi}

Pada tabel 3 (ANOVA), menunjukkan F-test sebesar 1,846 dengan tingkat signifikansi sebesar 0,126 dan mean std. Predicted Value sebesar 0,000. Nilai 0,126>0,000 sehingga dapat disimpulkan bahwa model regresi ini tidak dapat memprediksi return saham atau menunjukkan 
bahwa semua variabel independen yang diuji, yaitu CR, ROA, ROE, DER, dan TATO secara bersama-sama tidak mempengaruhi return saham.

Tabel 3

ANOVA

\begin{tabular}{|c|c|c|c|c|c|c|}
\hline \multicolumn{2}{|c|}{ Model } & $\begin{array}{l}\text { Sum } \\
\text { Squares }\end{array}$ & Df & Mean Square & $\mathrm{F}$ & Sig. \\
\hline \multirow[t]{3}{*}{1} & Regression & 0,005 & 6 & 0,001 & 1,846 & $0,126^{\mathrm{a}}$ \\
\hline & Residual & 0,014 & 28 & 0,000 & & \\
\hline & Total & 0,019 & 34 & & & \\
\hline
\end{tabular}

a. Predictors: (Constant), DPR (Z), ROE (X3), DER (X4), TATO (X5), CR (X1), ROA (X2)

b. Dependent Variable: Return Saham (Y)

Tabel 4

CoefficientS

\begin{tabular}{|c|c|c|c|c|c|c|c|}
\hline \multirow[b]{2}{*}{ Model } & \multicolumn{2}{|c|}{$\begin{array}{l}\text { Unstandardized } \\
\text { Coefficients }\end{array}$} & \multirow{2}{*}{$\begin{array}{c}\text { Standardized } \\
\text { Coefficients } \\
\text { Beta }\end{array}$} & \multirow[b]{2}{*}{$\mathrm{t}$} & \multirow[b]{2}{*}{ Sig. } & \multicolumn{2}{|c|}{$\begin{array}{l}\text { Collinearity } \\
\text { Statistics }\end{array}$} \\
\hline & B & $\begin{array}{l}\text { Std. } \\
\text { Error }\end{array}$ & & & & Tolerance & VIF \\
\hline $\begin{array}{c}1 \\
\text { (Constant) }\end{array}$ & 0,040 & 0,039 & & 1,004 & 0,324 & & \\
\hline $\mathrm{X} 1$ & 0,005 & 0,003 & 0,421 & 1,438 & 0,161 & 0,298 & 3,35 \\
\hline $\mathrm{X} 2$ & $-0,526$ & 0,279 & $-2,790$ & $-1,883$ & 0,070 & 0,012 & 85,777 \\
\hline $\mathrm{X} 3$ & 0,374 & 0,201 & 3,610 & 1,860 & 0,073 & 0,007 & 147,178 \\
\hline $\mathrm{X} 4$ & $-0,048$ & 0,045 & $-0,772$ & $-1,051$ & 0,302 & 0,047 & 21,105 \\
\hline $\mathrm{X} 5$ & $-0,036$ & 0,017 & $-0,900$ & $-2,077$ & 0,047 & 0,136 & 7,347 \\
\hline $\mathrm{Z}$ & 0,001 & 0,003 & 0,066 & 0,405 & 0,688 & 0,957 & 1,045 \\
\hline
\end{tabular}

a. Dependent Variable: Y (Return Saham)

Pada tabel 4 Coefficients dapat diketahui persamaan regresi yang dinyatakan sebagai berikut:

$\mathrm{Y}=0,040+0,005 \mathrm{X} 1-0,526 \mathrm{X} 2+0,374 \mathrm{X} 3-0,048 \mathrm{X} 4-0,036 \mathrm{X} 5$

Keterangan:

$\mathrm{Y} \quad=$ Return Saham $\quad \mathrm{X}_{3} \quad=$ Return on Equity

$\mathrm{X}_{1} \quad=$ Current Ratio $\quad \mathrm{X}_{4} \quad=$ Debt Equity to Ratio

$\mathrm{X}_{2} \quad=$ Return on Assets $\quad \mathrm{X}_{5} \quad=$ Total Assets Turnover

Berdasarkan tabel 4 tersebut, nilai konstanta sebesar 0,040 menunjukkan bahwa jika variabel independen tidak ada semua, maka return saham sebesar 0,040. Koefisien regresi pada Current Ratio $\left(\mathrm{X}_{1}\right)$ sebesar 0,005 menunjukkan bahwa setiap penambahan 1\% CR akan mengurangi return saham sebesar 0,005. Koefisien regresi pada ROA $\left(\mathrm{X}_{2}\right)$ sebesar $-0,526$ menunjukkan bahwa setiap pengurangan (tanda -) 1\% ROA akan mengurangi return saham sebesar 0,526. Koefisien regresi pada ROE sebesar 0,374, menunjukkan bahwa setiap penambahan $1 \%$ ROE akan menambah return saham sebesar 0,374. Koefisien regresi pada DER sebesar -0,048, menunjukkan bahwa setiap pengurangan (tanda -) 1\% DER akan mengurangi return saham sebesar 0,048. Sedangkan koefisien regresi pada TATO sebesar -0,036, menunjukkan bahwa setiap pengurangan (tanda -) 1\% TATO akan mengurangi return saham sebesar 0,036.

Pada kolom signifikansi yang terdapat pada tabel coefficients, memperlihatkan bahwa signifikansi pada masing-masing rasio, yaitu $\mathrm{CR}\left(\mathrm{X}_{1}\right)=0,161, \mathrm{ROA}\left(\mathrm{X}_{2}\right)=0,070, \mathrm{ROE}\left(\mathrm{X}_{3}\right)=$ 0,073, dan DER $\left(\mathrm{X}_{4}\right)=0,302>0,05$ dan dapat disimpulkan bahwa rasio-rasio tersebut tidak 
berpengaruh signifikan terhadap return saham, sedangkan TATO $\left(\mathrm{X}_{5}\right)$ memiliki nilai 0,047 dan nilai tersebut dibawah atau kurang dari 0,05 sehingga disimpulkan bahwa rasio TATO $\left(\mathrm{X}_{5}\right)$ berpengaruh signifikan terhadap return saham.

a. Pengujian Hipotesis Pertama $\left(\mathrm{H}_{1}\right)$

Pengujian hipotesis variabel CR berpengaruh terhadap return saham pada tabel 4 Coefficients memperlihatkan hasil tingkat signifikansi sebesar 0,161 dan tingkat signifikansi tersebut lebih besar dari Los ( Level of significance) 0,05, sehingga disimpulkan bahwa Ho diterima dan Ha tidak terdukung $(0,161>0,05)$. Berarti Current Ratio tidak berpengaruh secara signifikan terhadap return saham. Hal ini dimungkinkan investor lebih menyukai membeli saham-saham perusahaan dengan nilai rasio likuiditas yang rendah sehingga return saham yang diperoleh tinggi (Helfert, 2000). Kepemilikan terhadap aset lancar yang lebih besar tanpa kenaikan pengembalian (return) yang proposional akan mengakibatkan hasil pengembalian investasi menjadi turun.

b. Pengujian Hipotesis Kedua $\left(\mathrm{H}_{2}\right)$

Pengujian hipotesis variabel Return on Assets berpengaruh terhadap return saham pada tabel 4 Coefficients memperlihatkan hasil tingkat signifikansi sebesar 0,070 dan tingkat signifikansi tersebut lebih besar dari Los (Level of significance) 0,05, sehingga disimpulkan bahwa Ho diterima dan Ha ditolak $(0,070>0,05)$. Berarti Return on Assets tidak berpengaruh secara signifikan terhadap return saham. Berdasarkan analisis tersebut dimungkinkan bahwa perusahaan memiliki kemampuan untuk menghasilkan laba, akan tetapi laba yang dihasilkan kemungkinan untuk menutupi biaya modal dan biaya-biaya operasional maupun nonoperasional. Menurut Ball and Brawn (1968), menyatakan bahwa laba bukan merupakan satusatunya informasi akuntansi yang dibutuhkan oleh investor, karena investor dapat melihat indikator-indikator lain sebagai dasar pengambilan keputusan. Berdasarkan alasan tersebut, laba akuntansi yang tinggi maupun rendah bagi investor tidak akan mempengaruhi besar kecilnya return saham yang akan diperoleh. Penelitian ini didukung oleh penelitian dari Wulandari dan Sasongko (2006) yang menyatakan bahwa Return on Asset tidak berpengaruh signifikan terhadap harga saham.

\section{c. Pengujian Hipotesis Ketiga $\left(\mathrm{H}_{3}\right)$}

Pengujian hipotesis variabel Return on Equity berpengaruh terhadap return saham pada tabel 4.9 Coefficients memperlihatkan hasil tingkat signifikansi sebesar 0,073 dan tingkat signifikansi tersebut lebih besar dari Los (Level of significance) 0,05, sehingga disimpulkan bahwa Ho diterima dan Ha ditolak $(0,073>0,05)$. Berarti Return on Equity tidak berpengaruh secara signifikan terhadap return saham. ROE mencerminkan kemampuan perusahaan untuk menghasilkan laba berdasarkan aset yang dimiliki. Perusahaan memiliki aset yang tinggi tidak selalu dapat menghasilkan laba yang tinggi pula, akan tetapi jika laba yang diperoleh tinggi belum tentu akan dialokasikan ke return saham. Laba yang tinggi kemungkinan dialokasikan untuk menutup bunga hutang perusahaan.

Menurut Ball and Brawn (1968), menyatakan bahwa laba bukan merupakan satu-satunya informasi akuntansi yang dibutuhkan oleh investor, karena investor dapat melihat indikatorindikator lain sebagai dasar pengambilan keputusan. Berdasarkan alasan tersebut, laba akuntansi yang tinggi maupun rendah bagi investor tidak akan mempengaruhi besar kecilnya return saham yang akan diperoleh. Penelitian ini didukung oleh penelitian dari Wulandari dan Sasongko (2006) yang menyatakan bahwa Return on Equity tidak berpengaruh signifikan terhadap harga saham.

\section{d. Pengujian Hipotesis Keempat $\left(\mathrm{H}_{4}\right)$}

Pengujian hipotesis variabel Debt to Equity Ratio berpengaruh terhadap return saham pada tabel 4.9 Coefficients memperlihatkan hasil tingkat signifikansi sebesar 0,302 dan tingkat signifikansi tersebut lebih besar dari Los (Level of significance) 0.05, sehingga disimpulkan bahwa Ho diterima dan Ha ditolak $(0,302>0,05)$. Berarti Debt to Equity Ratio tidak 
berpengaruh secara signifikan terhadap return saham. Hal ini dimungkinkan investor tidak tertarik terhadap informasi mengenai tinggi rendahnya DER karena investor berasumsi bahwa saham itu tidak terlepas dari hutang yang ditanggung perusahaan. Hal ini didukung oleh penelitian dari Rosyadi (2002) yang menyatakan bahwa Debt to Equity Ratio tidak berpengaruh secara signifikan terhadap Perubahan Harga pada Perusahaan yang Listing di Jakarta Stock Exchange (JSE).

\section{e. Pengujian Hipotesis Kelima $\left(\mathrm{H}_{5}\right)$}

Pengujian hipotesis variabel Total Asset Turnover berpengaruh terhadap return saham pada tabel Coefficients memperlihatkan hasil tingkat signifikansi sebesar 0,047 dan tingkat signifikansi tersebut lebih kecil dari Los (Level of significance) 0,05, sehingga disimpulkan bahwa Ho ditolak dan Ha diterima $(0,047<0,05)$. Berarti Total Asset Turnover berpengaruh secara signifikan terhadap return saham. Hal ini dimungkinkan karena volume penjualan bersih lebih besar dibandingkan dengan tingkat aset yang dimiliki walaupun asset perusahaan juga tinggi. Hal ini menunjukkan perusahaan dapat menjalankan aktivitasnya dengan baik. Berdasarkan hasil koefisien regresi pada TATO sebesar -0,036, menunjukkan bahwa setiap pengurangan (tanda -) 1\% TATO akan mengurangi return saham sebesar 0,036. Dengan adanya pengurangan sebesar 0,036 terhadap return saham dan pengurangan tersebut memberikan pengaruh secara signifikan.

\section{Moderate Regression Analysis}

Moderate Regression Analysis digunakan untuk mengetahui gambaran mengenai pengaruh kinerja keuangan terhadap return saham dengan menjadikan kebijakan dividen sebagai variabel moderasi. Pengujian Moderate Regression Analysis dilakukan untuk mengetahui pengaruh kinerja keuangan terhadap return saham. Hasil pengujian Moderate Regression Analysis dapat dilihat dalam tabel 5.

\section{Tabel 5}

\begin{tabular}{|c|c|c|c|}
\hline Model & $\begin{array}{c}\text { Standardized } \\
\text { Coefficients }\end{array}$ & $\mathrm{t}$ & Sig. \\
\hline X1.Z & $-0,177$ & $-0,164$ & 0,871 \\
\hline X2.Z & $-0,703$ & $-1,105$ & 0,278 \\
\hline X3.Z & $-0,514$ & $-0,763$ & 0,451 \\
\hline X4.Z & 0,407 & 0,490 & 0,628 \\
\hline X5.Z & 0,719 & 0,764 & 0,450 \\
\hline
\end{tabular}

Pengujian kebijakan dividen yang dilihat melalui DPR (Z) sebagai pemoderasi pengaruh kinerja keuangan yang diwakili Current Ratio $\left(\mathrm{X}_{1}\right)$, Return on Asset $\left(\mathrm{X}_{2}\right)$, Return on Equity $\left(\mathrm{X}_{3}\right)$, Debt to Equity Ratio $\left(\mathrm{X}_{4}\right)$, dan Total Asset Turnover $\left(\mathrm{X}_{5}\right)$ terhadap return saham $(\mathrm{Y})$ menunjukkan nilai signifikansi sebesar secara berurutan adalah $0,871,0,278,0,451,0,628$ dan 0,450 , nilai signifikansi tersebut lebih besar dar nilao Los (Level of significance) yaitu 0,05 $(\alpha=5 \%)$, maka kebijakan dividen tidak mampu secara siginifikan memoderasi Current Ratio $\left(\mathrm{X}_{1}\right)$, Return on Asset $\left(\mathrm{X}_{2}\right)$, Return on Equity $\left(\mathrm{X}_{3}\right)$, Debt to Equity Ratio $\left(\mathrm{X}_{4}\right)$, dan Total Asset Turnover $\left(\mathrm{X}_{5}\right)$ terhadap return saham. Berdasarkan hasil pengujian Moderate Regression Analysis pada masing-masing variabel independen menunjukkan nilai signifikannya lebih besar dari 0,05 , maka $\mathrm{H}_{6}$ tidak terdukung dan dapat dinyatakan bahwa kebijakan dividen tidak mampu secara signifikan memoderasi pengaruh kinerja keuangan terhadap return saham.

\section{KESIMPULAN}

Penelitian ini dapat disimpulkan bahwa dari ke-lima variabel penelitian hanya empat variabel yaitu Current Ratio Return on Asset, Return on Equity, dan Debt to Equity Ratio yang tidak mempengaruhi return saham sedangkan Total Asset Turnover mampu mempengaruhi return saham hal ini dimungkinkan volume penjualan bersih lebih besar dibandingkan dengan 
tingkat aset yang dimiliki walaupun aset perusahaan juga tinggi. Hal ini menunjukkan perusahaan dapat menjalankan aktivitasnya dengan baik. Dan untuk variabel pemoderate yaitu kebijakan dividen tidak mampu memoderasi pengaruh kinerja keuangan terhadap return saham. Hal ini dikarenakan kebijakan dividen belum tentu dapat meningkatkan return saham perusahaan pada saat Current Ratio, Return on Asset, Return on Equity, Debt to Equity Ratio rendah dan pada saat Total Aset Turnover tinggi begitupun sebaliknya.

Peneliti menyadari bahwa hasil dari penelitian ini masih belum sempurna. Hal ini dikarenakan masih terdapat beberapa keterbatasan-keterbatasan sebagai berikut. Penelitian hanya meneliti faktor faktor yang diduga berpengaruh terhadap return saham yaitu Current Ratio Return on Asset, Return on Equity, Debt to Equity Ratio, danTotal Asset Turnover. Penelitian ini hanya meneliti return saham pada sektor manufaktur saja yang dianggap mendominasi pasar modal dan penelitian hanya meneliti perusahaan selama 5 tahun sehingga hanya mampu melihat pengaruh variabel independen terhadap variabel dependen pada periode yang pendek. Berdasarkan hasil penelitian yang telah dilakukan, saran yang dapat diajukan untuk penelitian selanjutnya adalah penelitian selanjutnya menambahkan variabel-variabel lain yang diduga berpengaruh terhadap return saham untuk dijadikan objek penelitian baik faktor internal maupun eksternal, selain itu penelitian selanjutnya hendaknya meneliti return saham pada sektor usaha lain yang masih jarang diteliti, misalnya pada perusahaan perbankan, real estate atau jasa dan penelitian selanjutnya akan lebih baik jika menambah periode waktu penelitian karena akan lebih mengetahui bagaimana pengaruh yang terjadi jika penelitian dilakukan dalam periode yang lebih lama.

\section{DAFTAR PUSTAKA}

Ball, Ray dan Philip Brown. 1968. An Empirical Evaluation of Accounting Income Numbers.

Dalam buku Positive Accounting.

Brigham, Eugene F., and Houston. Joel F. 2001. Manajemen Keuangan. Jakarta : Erlangga.

Hanafi, Mamduh. 2003. Manajemen Keuangan, BPFE, Yogyakarta.

Harahap, Sofyan Syafri., 2004. Analisis Kritis Atas Laporan Keuangan. Jakarta: PT Raja Grafindo Persada.

Hardjito, Agus, dan Martono. 2005. Manajemen Keuangan. Edisi Kelima. Yogyakarta : EKONISIA.

Helfert, Erick A. 2000. Technique of Financial Analysis. A Guide to Value Creation, Mc. GrawHill. Edisi Indonesia.

Husnan, Suad. 2003. Dasar- Dasar Teori Portofolio dan Analisis Sekuritas. Edisi Ketiga. Cetakan Ketiga. Yogyakarta: Penerbit UPP AMP YKPN.

Jogiyanto, H. M. 2007. Teori Portofolio dan Analisis Investasi. Yogyakarta: BPFE.

Kieso, Donald E., Weygandi, Jerry D., Warfield, Terry D., 2002. Akuntansi Intermediate, Jilid 1, Edisi Kesepuluh. Jakarta Erlangga.

Kurniawati, Indah. 2006. Mengolah Statistik dengan SPSS 11.5. Yogyakart ; Penerbit Universitas Ahmad Dahlan Yogyakarta.

Munawir, S. 2003. Analisa Laporan Keuangan. Yoyakarta: Liberty.

Pradhono dan Christiawan, Yulius Jogi.“ Pengaruh Economic Value Added, Residual Income, Earnings dan Arus Kas Operasi Tarhadap Return yang Diterima oleh Pemegang Saham (Studi Kasus pada Perusahaan Manufaktur yang Terdaftar di Bursa Efek Indonesia)".

Raharjo, Susilo. 2005. Analisa Kinerja Keuangan Terhadap Return Saham pada Perusahaan LQ45 di Bursa Efek Jakarta. Skripsi . Yogyakarta: Universitas Islam Yogyakarta.

Riyanto, Bambang., 2001. Dasar-dasar Pembelanjaan Perusahaan. Edisi Empat. Yogyakarta: BPFE.

Rosyadi , Imron. 2002. “ Keterkaitan Kinerja Keuangan dengan Harga Saham (Studi pada 25 Emiten 4 Rasio Keuangan di BEJ)" Jurnal Akuntansi dan Keuangan (April), hal. 24-28.

Wulandari, Nila., dan Noer Sasongko. 2006. " Pengaruh EVA dan Rasio-Rasio Profitabilitas Terhadap Harga Saham. 